\title{
The Effect of Mathematics and Physical Science on Matriculants' Overall Performances: Analysis Using
} Multilevel Model

\author{
ME Letsoalo \\ Tshwane University of Technology, Pretoria, South Africa \\ MaupiELetsoalo@gmail.com
}

\begin{abstract}
This comparative, cross-sectional, quantitative and ex-post-facto designed study used secondary and correlated data to compare the likelihood of passing matric between learners from Gauteng and Western Cape provinces, even after adjusting for subject-type. This study attempted to assess the relation between school resources input, subject offered, learner's gender and learners' academic achievements. The data used in this study were supplied by the Umalusi Council. The dataset contained 145783 matric learners (65245 [44.75\%] males and 80538 [55.25\%] females) who wrote the matric examinations in Gauteng and Western Cape provinces in November 2009. The unadjusted model indicated that learners in Western Cape were significantly 1.193 more likely to pass matric than learners in Gauteng province $(\mathrm{p}<0.001, \mathrm{OR}=1.193$, 95\%CI: 1.164 - 1.223). The adjusted model results indicated that learners in the Western Cape province were 1.5122 more likely to pass matric when compared to learners in Gauteng province $(\mathrm{p}<0.001, \mathrm{OR}=1.512$, 95\%CI: 1.471 - 1.555). These results indicate that the odds of passing matric, after adjusting for science subjects, increased in favour of learners in the Western Cape Province. It can be concluded that the Western Cape Province provides more enabling conditions to ensure matriculants' superior performance. It is suggested the strategies to improve the quality of mathematics and science educators need to be implemented, especially in Gauteng province. Also, the policy that advocates for the differentiation approach should be adopted, as opposed to the current policy that advocates for a more general, rigid approach that does not recognise the inherent differences in the provinces.
\end{abstract}

\section{Keywords: Adjusted model, matric, Odds ratio, Academic performance, School quintile}

\section{Introduction}

Prior to 1994, South Africa had four provinces, as presented in Figure 1: the Transvaal and Orange Free State, formerly Boer republics, and Natal and the Cape provinces, former British colonies. Scattered in between these were "homelands" or Bantustans, some form of states in which black South Africans were forced to have citizenship.

Figure 1: Province of South Africa before 1994

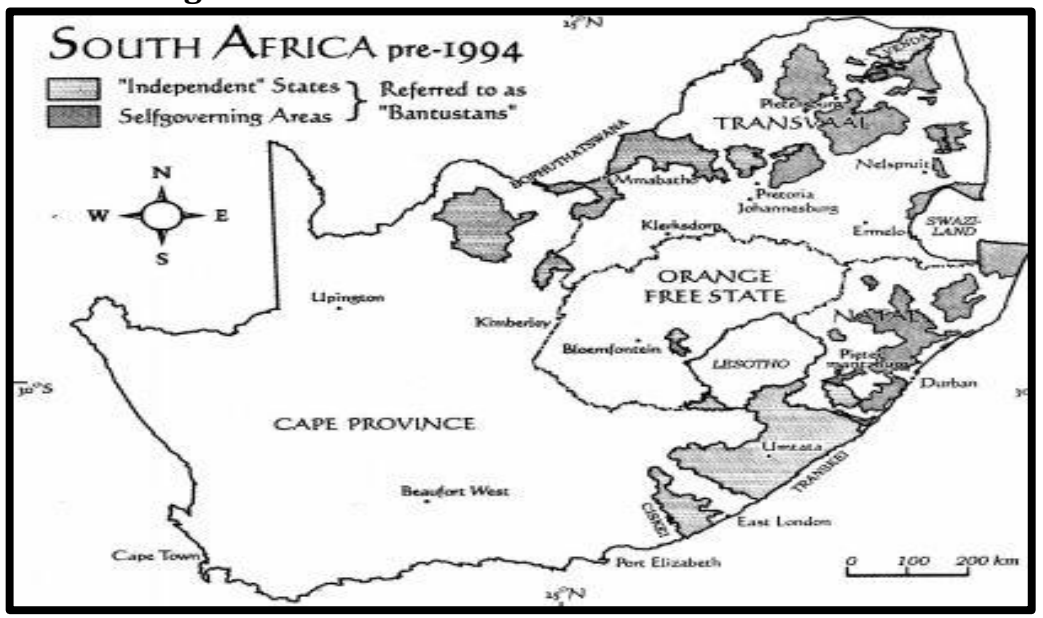

The Bantu Education Act, 1953 (Act No. 47 of 1953, later renamed the Black Education Act, 1953) was a South African segregation law. Its major focus was provision of racially segregated educational facilities. This meant that all citizens did not have equal opportunities to education. In particular, the majority of black South African citizens were denied the right to quality education. The Minister of Native Affairs at the time, the 
"Architect of Apartheid", stated his opinion, that resonated with many Afrikaners, that (Clark \& Worger, 2004)"...there is no place for [the Bantu] in the European community above the level of certain forms of labour ... What is the use of teaching the Bantu child mathematics when it cannot use it in practice?". The European community is referred to as White South Africans that included the Afrikaners while the black people were Bantu. Bansilal, James \& Naidoo (2010)quoting the Department of Education (1997) states that education reform in South Africa was heralded by the introduction of the new curriculum framework called Curriculum 2005 and later the National Curriculum Statement in 2003 (Department of Education, 2003). The aim of these documents was to address the poor quality of education that many South African learners had been exposed to. While mathematics and physical science are (generally) thought of as or perceived to be difficult subjects by many in South Africa this type of folly, fallacy (Letsoalo, Maoto, Masha, \& Lesaoana, 2016; Letsoalo, 2017b) or myth was mainly perpetuated by the political system.

In 1994 - under South Africa's new democratic dispensation, the country was demarcated into nine provinces - each with its own provincial government, with legislative power vested in provincial legislature, as presented in Figure 2. The Western Cape Province, situated in the former Cape Province, and Gauteng province, situated in the former Transvaal, are metropolitan provinces. In other words, most of their municipalities are metropolitan. A language spoken by majority of citizens in the Western Cape Province is Afrikaans, while Gauteng province has a reasonable distribution of all 11 South African official languages. Prior to 1994 quality service delivery was on racial lines. Currently, the focus seems to have shifted to gender differences and the discrepancies among provinces.

Figure 2: Province of South Africa since 1994

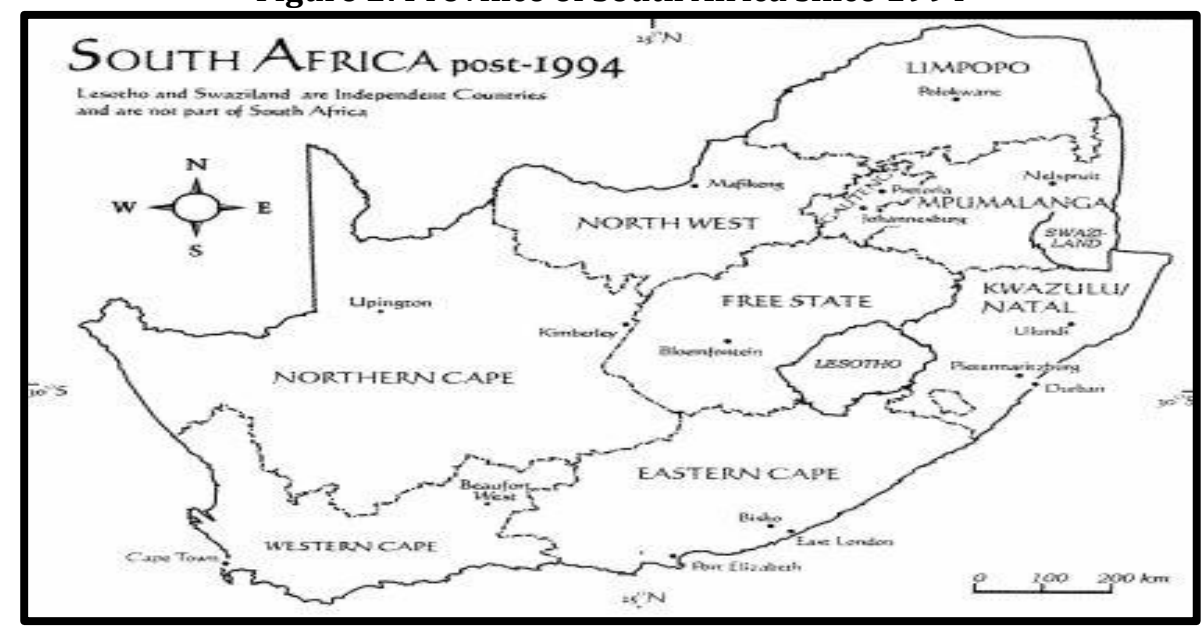

Education is a key component that is essential for generating high incomes and sustainable socio-economic development (Ojera, 2016). It is an essential ingredient in poverty eradication. In the modern technological world, education is considered as the first step for every meaningful human activity. It plays an important role in the development of human capital and is linked to an individual's well-being and opportunities for better living conditions (Battle \& Lewis, 2002; Kyei \& Nemaorani, 2014). The South African government has made significant strides in developing inclusive education policies when compared to other African states (Dalton, Mckenzie, \& Kahonde, 2012). In inclusive education, which refers to an education system where learners with learning barriers attend the same classes as learners who do not experience learning barriers, all stakeholders, including learners, participate as equal members of society. In other words, the education system caters for learners with learning barriers and those without. They learn together in the same conditions, but use materials appropriate to their various needs (Kanjere \& Mafumo, 2017). Therefore, there must be harmony among all components of the system if the system is to function properly and yield the required outcomes. The main challenge with inclusive education is a lack of adequate resources to support the objectives of the system. In South Africa, little has been done to prepare the educators and school principals to embrace the trajectory in education. Educators are battling to adapt the curricula to meet the diverse range of learning needs. Apart from challenges presented by inclusive education, teaching and learning mathematics and physical science has been fraught with difficulty over many years. While 
mathematics, physical science and (some) technological subjects (STEM) are taught as separate subjects at school, presenting the STEM subjects in an integrated fashion will strengthen understanding of all of them. Therefore, a major challenge that exists is to transform science studies into an inquiry-driven, project-based learning domain by staff development or capacity development.

Mathematics is a unique subject that is a fundamental component of a school curriculum. It forms the basis for the development of all other sciences. In South Africa, all learners have to take mathematics, with majority of learners being enrolled for mathematics literacy. Therefore, in South African school settings mathematics consists of mathematics literacy and pure mathematics. Researchers reported a significant relationship between mathematics and physical science (Adeyemi, 2007; Charles-Ogan \& Okey, 2017; Ogunleye, Awofala, \& Adekoya, 2014). They assert that the effectiveness in learners' understanding and application of concepts in physical science can be guaranteed through adequate possession of mathematics knowledge. Adequate skills in and knowledge of mathematics and physical science are believed to be vital to success in modern life and socio-economic prosperity. Knowledge of mathematics is an essential tool for all members of society (Letsoalo, 2017b). As underscored by Carnevale (2005) in the current highly technological economic world, mathematics education and mathematics performance are key resources in the global context. It is a matter of concern that the TIMSS (Trends in International Mathematics and Science Study) found the average mathematics performance of South African learners in Grade 9 to be well below the international benchmark of 500 points (Visser, Juan, \& Feza, 2015). In fact, the country was placed in the bottom 6 of 63 participating countries in terms of mathematics performance.

Proficiency in mathematics and physical science is increasingly recognised as fundamental to economic success for individuals and nations (Stevens, Wang, Olivarez, \& Hamman, 2007). The importance of mathematics extends to the support and contribution to the purposes of general education (Breslich, 1966). In fact, knowledge of science (mathematics and physical science) in modern society cannot be downplayed. However, has emerged that these subjects are not easily accessible to all learners due to the demands they present (Letsoalo, 2017b). Scarpello (2007) reports that 75\% of Americans gave up studying mathematics early and stay away from many careers that are related to mathematics. He identifies mathematics anxiety as one of the main reasons for this. According to Campbell \& Prew (2014) the South African Department of Basic Education's reports indicate a $17 \%$ decline in the number of candidates who wrote mathematics between 2009 and 2013 (from about 290400 to 241400). At the same time, the number of candidates writing mathematics literacy rose sharply to $58 \%$ of the 2013 cohort. Likewise, the number of candidates who wrote physical science fell by about $17 \%$ over the same period (from 220900 to 184300). As the number of learners who elect to do mathematics drops, the overall number of learners who achieve an NSC pass with more than $40 \%$ in mathematics has been falling over the same period to $17 \%$ of the class of 2013 . This means the national pool of students who are able to do a degree which requires mathematics is very limited. These include degrees such as engineering, law, accountancy and teaching degrees in mathematics and physical science. Owing to the dwindling numbers of learners who are successful in mathematics and physical science, South African learners generally have poor science skills (Bansilal, James, \& Naidoo, 2010).

Apart from logical reasoning, understanding mathematics and physical science is a significant feature in the process of mathematics and physical science learning. Policy makers, education stakeholders, educators and researchers continue to grapple with the following questions: How can we understand the difficulties, frequently insurmountable, that many learners have with comprehension of mathematics and/or physical science? What is the nature of these difficulties and where are they encountered? As stated to by Lilis \& Togi (2017), these questions have taken on a particular magnitude and gravity with current pressure for more mathematical and physical science training to be given to all learners to prepare them to operate in a technological and computer-oriented environment of perpetually increasing complexity. The questions present an educational challenge in classrooms (or in the school setting) as well as a theoretical challenge to research the development and learning of mathematical and physical science knowledge. The process of mathematical knowledge acquisition is so complex that new approaches are required. This paper makes no attempt to answer these questions, because its objective is to determine the effect of mathematics and physical science on the overall performances of matriculation learners in two provinces of South Africa. Matriculation (or matric), sometimes called Grade 12 is the final year of secondary or high school in South Africa. 


\section{Literature Review}

Studies have been conducted to determine factors that affect learners' performance (Kyei \& Nemaorani, 2014; Letsoalo, 2017b; Letsoalo, Maoto, Masha, \& Lesaoana, 2017). It is accepted that learning is influenced by many factors, both cognitive and non-cognitive, also called affective factors (Letsoalo, 2017a). Cognitive factors include memory, verbal abilities and an aptitude for reasoning. These can be measured by setting performance and achievement tasks, where the answers given can be grouped as correct or incorrect, or acceptable or unacceptable. In other words, cognitive ability refers to an individual's ability to process, abstract, reason, remember and relate information. Though cognitive ability assessments are often thought of as measures of education, they are rather measures of more general mental capabilities. However, cognitive ability can be measured by an intelligence quotient (IQ) test. As highlighted by, among others, Kyei \& Maboko (2016) and Letsoalo (2017a), for decades many non-cognitive factors have affected performance. Consequently the research community is now focused on affective factors. Affective factors are:

Learner attributes or characteristics: Many studies have explored gender disparities and differences among learners. Gender disparities exist in the areas of schooling, academic achievement and school experience. Filmer (2005) reports that, partly due to school gendered structure of the school experience (Chowa, Masa, Ramos, \& Ansong, 2015), enrolment at schools is significantly lower for female learners than it is for male learners. Tansel (2002) reports that, although high levels of enrolment have been achieved at the primary school level for both male and female learners in much of Turkey, substantial regional differences remain. In particular, in the south-eastern region, female learners begin to drop out of school around the third grade. A mother's level of education has a significant effect on female learner's enrolment (Tansel, 2002; Chowa, Masa, Ramos, \& Ansong, 2015). In the study that sought to compare the overall chances of passing matric or Grade 12 between male and female learners in Gauteng province, Letsoalo (2017a) reports that the overall Grade 12 performance levels of male and female learners are significantly different, with female learners performing better. Demirbas \& Demirkan (2007) and Sunday \& Zaku (2013) warn that findings on gender are inconclusive since researchers have different opinions based on their findings regarding the effect of gender on learners' academic performance.

How learners perceive (and think about) school is an important predictor of learner achievement (Chowa, Masa, Ramos, \& Ansong, 2015). Among other factors, a learner's self-concept, self-efficacy, attitude, and motivation are positively related to academic achievement (Adewuyi, Taiwo, \& Olley, 2012; Barrows, Dunn, \& Lloyd, 2013; Chowa, Masa, Ramos, \& Ansong, 2015). Furthermore, test anxiety affects learners negatively. This effect is increased if the anxiety is dealt with in an unhealthy manner and extends over a long period of time (Barrows, Dunn, \& Lloyd, 2013). Fentiman, Hall \& Bundy (1999) report that a learner's age is significantly linked to the learner drop-out rate and somewhat associated with learner performance, as well as learner attitude and motivation.

Home factors: A learner's background is considered to be the crucial factor that influences a learner's performance. The community, which includes parents, constitutes part of this background. Sudhir \& Lalhirimi(1989) and Jehangir, Tahir \& Saeed (2000) explain that parental education is an index of class status and some personality characteristics of learners. Learners of educated parents have a high level of satisfaction and fewer problems than learners of less educated parents or totally uneducated parents. The latter group have low emotional stability and high anxiety levels. Faize \& Dahar (2011) reported that the performance of learners with educated mothers was better than those with illiterate mothers. However, as the level of mother's education rose, the difference in science learners' scores was not significant. This indicates that a certain minimum level of a mother's education is required for better learner performance. Englund, Luckner, Amy \& Egeland (2004) opine that mothers with higher education are able to provide more support to their children in problem-solving situations at pre-school level, and that this early involvement by educated mothers contributes to high or better academic performance or achievement at later stages of schooling. Peters \& Mullis (1997) reported that a mother's education level has an effect that is $20 \%$ higher than the father's education level on the academic outcomes of adolescents. Consumption of alcoholic beverages has a long history in South Africa dating back to ancient times (Kyei \& Ramagoma, 2013). During pre-colonial days the consumption of alcohol was the preserve of elders, and other senior or authoritative figures, including health practitioners and traditional healers. Currently, in some households, drugs and 
alcohol abuse are factors that contribute to learners' absenteeism. The consequences of missing classes are likely to be decreased motivation or poor academic performance by learners.

School characteristics: At school level, socio-economic status (SES) is by far the single most important factor that accounts for the varying levels in learner performance (Rogers, 1997). Socio-economic status, commonly conceptualised as the social standing or class of an individual or group, is an economic and sociological combined total measure of a person's work experience and of an individual's or family's economic and social position relative to others, based on income, education and occupation(Letsoalo, 2017a; Letsoalo, Maoto, Masha, \& Lesaoana, 2017). Education research practitioners use wealth or SES measures as surrogates for well-being. Although many studies have been conducted on the effect of school resources on learner achievement, the question is far from settled (Hakkinen, Kirjavainen, \& Uusitalo, 2003). South African schools are categorised or classified into five groups, called quintiles, largely for purposes of allocation of financial resources. The poorest schools are in quintile 1 , while the well-resourced schools are in quintile 5 . Schools in quintiles 1, 2 and 3, mostly located in rural areas, are no-fee schools, while schools in quintiles 4 and 5 mostly located in urban and semi-urban areas, are fee-paying schools. In the study that sought to compare the likelihood of passing Grade 12 between male and female learners; Letsoalo (2017a) reported that learners' performances were significantly affected by the school quintile. Therefore, the location, structure, resources and social atmosphere of a school can often be linked to its learners' academic success (Chowa, Masa, Ramos, \& Ansong, 2015, p. 131). Closely associated with school environment is educator quality. Stakeholders in education consider educator quality to be the most important determinant of learner performance. Parents may send their children to distant schools due to the fact that those nearby are said to have poor education or poor teaching quality.

Interaction of learner, home and school factors: The quality of interaction among learner, home and school has the potential to exacerbate disparities. As educators and resources are seem to affect the performance of learners, well-resourced schools that employ quality educators are more likely to produce better results. Similarly, under-resourced schools with unqualified or under-qualified educators are more likely to produce poor results. Lee, Zuze \& Ross (2005) maintain that the effects of school and educator resources play various roles on the learning process of learners depending on the learners' SES. Motivation has a significant effect on learners' performance. Learners' motivation levels seem to decrease throughout the primary school years and then increase again just before the transition to secondary education (Eccles \& Midgley, 1989). A lack of 'person-environment' fit has the potential to increase motivation. This implies poor integration of a learner's personal world into the school environment (Thoonen, Sleegers, Peetsma, \& Oort, 2011). In South Africa, the introduction of outcomes-based education (OBE) paved the way for greater parent involvement in education. The new system expects parents to play a crucial role in the education system because they are required to share the responsibility of education with the state (Department of Education, 1997).

Furthermore, the new system requires parents to use knowledge gained to build and develop their community and the country. For most parents, the first hurdle is to understand how the new curriculum works and then to get involved with the governing bodies of schools. The system has to produce a new generation of learners who are well-equipped to deal with the challenges of a changing world. Transformational OBE expects the parents to perform a number of duties pertaining to education. Learners, educators and the community are expected to become a single, united voice in shaping the curriculum of the school (Singh, Mbokodi, \& Msila, 2004). As highlighted by Fan \& Chen (2001), parental involvement is operationally defined as parental aspirations for their children's academic achievement and parents' transfer of such aspirations to their children. These include parents' communication with children about school, parents' participation in school activities, parents' communication with teachers about their children, and the rules parents impose at home which can be considered to be school-related. This somewhat chaotic state in the definition of the main construct not only makes it difficult to draw any general conclusion across studies, but also could have contributed to the inconsistencies in the findings in this area. An alarm has been sounded about critical workforce shortages in those positions that require high-level mathematical and science skills (Stevens, Wang, Olivarez, \& Hamman, 2007). Their fear about a dwindling pool of mathematicians and scientists has fuelled concern that countries, such as South Africa (in Africa) and United States (world-wide), will not be able to maintain their leadership in science and technology (Halpern, et al., 2007). 
Driven by equity concerns and worries about insufficient capacity building in science, low female representative in the physical sciences continues to be a topic of priority among scientists, educators, policy makers and education researchers. While physical science can be learnt through observation, language and vocabulary are foundational. Students are able to observe chemical reactions, watch things change and observe interactions, but there are many students who do not understand the language and concepts. They cannot appreciate the importance of words, and/or confuse salient, critical terms.

In the study that sought to determine whether or not the status of the teacher has any impact on the performance of students in physics, Owalabi (2012) examines the effect of teachers' qualifications on the performance of senior secondary school physics students. The study concludes that learners taught by educators with higher qualifications perform better than those taught by educators with low qualifications. The results also reveal that learners taught by professional educators perform better, while educators' experience in teaching the subject is a significant advantage in physics.

High-quality staff development is a central component in nearly every proposal for improving education. In other words, staff development lies at the heart of almost every educational effort to improve learners' performances and achievements. Staff development programmes are designed to "alter the professional practices, beliefs, and understanding of school persons toward an articulated end" (Griffin, 1983). In his review of the literature on professional development, Guskey (1986) notes that nearly every major work on the topic of staff development discredits its efficacy. He attributes these historically dismal results to a poor understanding of educators' motivation and a lack of insight into both the individual and environmental factors in the process of change. In Abe's (2014) examination of the effect of educators' qualifications on learners' performance in mathematics, the results show that a significant difference exists between learners taught by professional educators and those taught by non-trained educator.

Unlike biological science, the physical sciences continue to have female underrepresentation with some of the largest gaps occurring in physics (Hazari, et al., 2013). There has been wide speculation about why such disparities continue to prevail. Gender differences in secondary mathematics are a prominent issue that has been the focus of many studies (Letsoalo, Maoto, Masha, \& Lesaoana, 2016; Letsoalo, 2017a), with reported discrepancies in mathematics achievement of female and male learners being a contentious issue. Researchers have no reached consensus. Many studies that looked at the gender differences have mixed findings (Letsoalo, Maoto, Masha, \& Lesaoana, 2017). While some studies show female learners outperforming male learners, notably those by Stevens, Wang, Olivarez \& Hamman(2007), others report that the difference in performance between male and female learners is marginal (e.g., Letsoalo, Maoto, Masha \& Lesaoana (2017)). Some even find male learners outperforming female learners notably Preckel, Goetz, Pekrun \& Kleine (2008), Asante (2010), Stoet \& Geary (2013) and Letsoalo (2017a).

The usual interpretation of attitude refers to someone's either liking or disliking a common target. Studies show that female learners tend to have a more negative attitude towards mathematics than their male counterparts (Hannula, 2002) with that attitude tending to become more negative as learners progress from primary to secondary or high schools (McLeod, 1994). An attitude to mathematics or physics is a complex mix of negative or positive emotions that are associated with mathematics, as well as individual beliefs regarding mathematics and behaviour associated with mathematics (Hart, 1989). The general attitude of a class towards mathematics can be related to the quality of the teaching and the social-psychological climate of the class (Haladyna, Shaughnessy, \& Shaughnessy, 1983). Together with attitude, researchers have found that stereotyping plays an affective role in human life. Stereotype threat is a phenomenon in which the activation of a self-relevant stereotype leads people to show stereotype-consistent behaviour, thereby perpetuating the stereotyping. In other words, researchers have found that priming a social category can automatically elicit stereotype-consistent behaviours that usually manifest in decreased intellectual performance (Steele \& Ambady, 2006).

Theoretical Framework-This study is based on:

a) the supervision theory as developed by Robinson (1968). According to this theory, supervision in the education sector is necessary to ensure that there are an adequate number of qualified educators, good 
orientation programmes and availability of supplies and equipment. The theory postulates that supervision reassures educators that they do good work. This earns them recognition and builds confidence. The theory also states that supervision of classroom instruction is necessary to ensure that the functions of all educators are co-ordinated. According to the theory, educators differ in degrees of professional competence and in their need for advice regarding their classroom work. This theory identifies five important functions of supervision in the provision of quality education. These include: proper teaching methods, relevant teaching material, a sound learning environment, efficient school management and effective administration of funds. This study sought to find out after adjusting for school quintile in the multilevel model, how the matriculants performed in the two provinces.

b) the theory of human motivation is also called Maslow's hierarchy of needs (Maslow, 1943). This theory emphasises the role of human motivation to bring out the best possible outcomes in human efforts. According to this theory, a human-being is constantly preoccupied with a need that must be met at a point in time. This gives rise to another need which will not necessarily be satisfied in the long run.

Figure 2: Maslow's hierarchy of needs

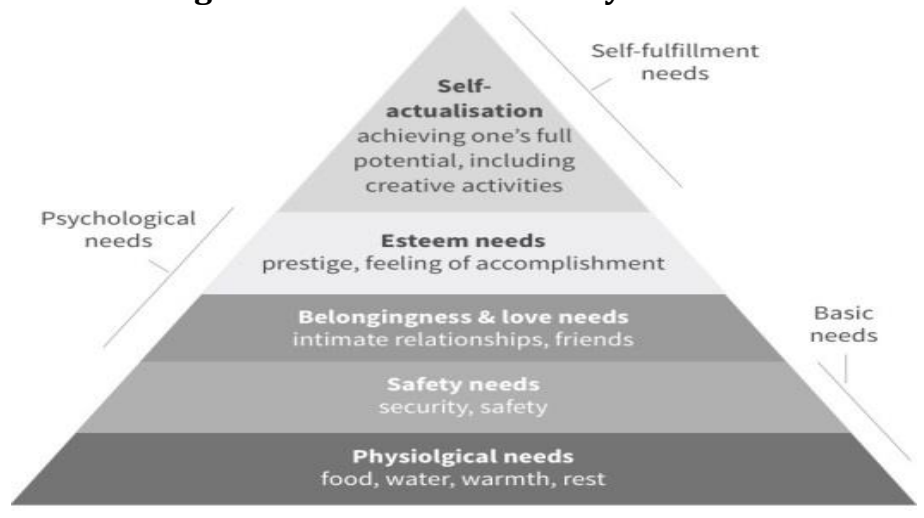

This theory postulates that the satisfaction of a stage of need will automatically give rise to the next level of need (Maslow, 1943). In other words, human beings are fuelled by a desire to achieve goals. Attaining goals helps to satisfy specific needs and desires. Needs are categorised into a hierarchy, where certain needs must be met before others can be assessed (Maslow, 1943). Lower needs must be satisfied before higher-order needs can be reached. When learners are concerned about certain needs, their behaviours centre on meeting those needs. Other concerns will take precedence over learning and achievement. Therefore, is a need has not been met or has been neglected; this can affect a learner's performance and behaviour at school negatively. This theory tries or attempts to provide an understanding of why learners behave the way they do. It assists in determining how learning can be affected by factors such as physiological or safety concerns. This study is underpinned by the theory of human motivation. Figure 2 is a schematic representation of Maslow's hierarchy of needs.

Purpose of the study: The purpose of this study was to investigate the effect of mathematics and physical science, collectively called science, on the overall learners' academic performance in the Western Cape and Gauteng provinces. Specifically, the study sought to determine to what extent does science influenced academic performances of learners in the two provinces. It aimed at comparing the overall performance of matriculants in Gauteng and Western Cape provinces. The null hypothesis that matriculants in Gauteng and Western Cape provinces did not perform significantly differently was tested at $\alpha=0.05$ (2-sided) or 95\% confidence limit.

The guiding question was:

Do matriculants in Gauteng and Western Cape provinces have different chances of passing matric, even after adjusting for subject-type (mathematics, physical science, English and others)?

To achieve this, the researcher intended to draw inference at the province-level, the unit of analysis (Murray, 1998; Letsoalo, Maoto, Masha, \& Lesaoana, 2016). This is the first study to be conducted that compares the 
overall performances of matriculants in Gauteng and Western Cape provinces, wherein crude estimates and adjusted estimates were determined. Specifically, this is the first study that determined the effect of science on the overall performance of matriculants. The adjusted covariates were learner-gender, school quintile and subject-type. The study end-point was binary, which indicated whether or not a learner passed matric.

\section{Methodology}

This comparative, cross-section quantitative study followed an ex-post-facto design (Cohen, Manion, \& Morisson, 2000), and used secondary and clustered data called Grade 12 dataset, supplied by Umalusi, the Council for Quality Assurance (CQA) in General and Further Education and Training (FET) in South Africa. Grade 12 data requires multilevel models to account for clustering (Skrondal \& Rabe-Hesketh, 2004; RabeHesketh \& Skrondal, 2005). These models are a more advanced form of simple and multiple linear regression models (Letsoalo, Maoto, Masha, \& Lesaoana, 2016). The classical regression models, adopted to investigate the relationships between one or more independent variables and a dependent one, are based on the hypothesis of non-correlation between observations. The analysis of the individuals as non-correlated could lead to distortions, namely underestimation of standard error of the model or the attribution of non-existing statistical effects between the variables (Wu \& Zhang, 2006). The Grade 12 data comprises of pseudo-learner identifiers, learning area (school subjects) per learner, final outcome, final score (\%), province (Gauteng or Western Cape provinces), learner gender (male or female), school quintile and examination centre (school identifier). Statistical data analysis was accomplished by using the statistical software package called Stata V15 (StataCorp, 2017). Summary statistics for all categorical variables were presented as frequencies and percentages. The study end-point was whether or not a learner passed Grade 12 (passed or not passed). Multilevel data analysis for binary end-point, also called hierarchical logistic regression modelling was used to compare the overall performance of learners and to determine the effect of science subjects on the overall performances of learners in the two provinces. The interpretation of the results was performed at $95 \%$ confidence limit or 0.05 error rate.

\section{Results and Interpretation}

A binomial logistic regression or simple logistic regression predicts the probability that an observation falls into one of two categories of a binary dependent variable based on one or more independent variables that can be either continuous or categorical (Hosmer, Lemeshow, \& Sturdivant, 2013). A simple logistic regression model assumes that the observations are independent. In case of dependent observations, the model that accounts for intra-cluster correlation coefficient is plausible. The data used in this study are typical clustered or correlated data. Multilevel logistic regression models, both crude (null) and adjusted models (RabeHesketh \& Skrondal, 2005; Wu \& Zhang, 2006), were used to determine the likelihood of observing the outcome 'passed matric' between learners in the two provinces. The parameter of interest is odds ratio (OR), which is used to compare the relative odds of the occurrence of the outcome of interest, given exposure to the variable of interest (Szumilas, 2010; Hosmer, Lemeshow, \& Sturdivant, 2013; Letsoalo, 2017a). Possible interpretation of OR is presented in Table 1 (Szumilas, 2010; Letsoalo, 2017a).

\section{Table 1: Interpretations of odds ratios}

\begin{tabular}{ll}
\hline Odds Ratio (OR) & Interpretation \\
\hline Less than $1(\mathrm{OR}<1)$ & $\begin{array}{l}\text { Exposure associated with lower odds of outcome, suggests that the } \\
\text { odds of exposure are negatively associated with the adverse outcomes } \\
\text { compared to the odds of not being exposed. } \\
\text { Exposure does not affect odds of outcome. This suggests that there is } \\
\text { no difference between the groups; namely there would be no } \\
\text { association between the suggested exposure and the outcome. } \\
\text { Exposure associated with higher odds of outcome, suggests that the } \\
\text { Greater than } 1(\mathrm{OR}>1)\end{array} \quad \begin{array}{l}\text { odds of exposure are positively associated with the adverse outcome } \\
\text { compared to the odds of not being exposed. }\end{array}$
\end{tabular}
Association does not necessarily imply causation 
a) Descriptive Statistics: The participants in the study were 145783 matriculants (65245 [44.75\%] males and 80538 [55.25\%] females) who wrote the 2009 matriculation examinations in Gauteng and Western Cape provinces. The number of female participants was marginally higher than that of males in the two provinces. Table 2 shows that there were marginally more female learners than male counterparts in Gauteng Province (56.89\% vs. $43.11 \%$ ) and in the Western Cape Province (54.48\% vs. $45.52 \%$ ).

Table 2: Distribution of gender by province

\begin{tabular}{lcccl}
\hline Gender & \multicolumn{2}{c}{$\begin{array}{c}\text { Western Cape } \\
\text { province }\end{array}$} & \multicolumn{2}{c}{$\begin{array}{c}\text { Gauteng } \\
\text { province }\end{array}$} \\
& Count & Percent & Count & \multicolumn{1}{c}{ Percent } \\
\hline Male & 19930 & 43.11 & 45315 & 45.52 \\
Female & 26304 & 56.89 & 54234 & 54.48 \\
Total & 46234 & 100.00 & 99549 & 100.00 \\
\hline
\end{tabular}

Table 3 indicates that the number of matriculants in Gauteng province was higher than that in the Western Cape Province (99549 vs. 46234). However, the proportion of learners who passed matric was marginally higher in the Western Cape Province (73.93\%) than in Gauteng Province (70.42\%). The proportion of matriculants who did not pass was marginally higher in Gauteng Province $29.59 \%)$ than in the Western Cape Province (26.04\%).

Table 3: Distribution of results in the provinces

\begin{tabular}{|c|c|c|c|c|}
\hline \multirow{2}{*}{ Result } & \multicolumn{2}{|c|}{$\begin{array}{l}\text { Western Cape } \\
\text { province }\end{array}$} & \multicolumn{2}{|c|}{$\begin{array}{l}\text { Gauteng } \\
\text { province }\end{array}$} \\
\hline & Count & Percent & Count & Percent \\
\hline $\begin{array}{ll}\text { Did } & \text { not } \\
\text { pass } & \end{array}$ & 12040 & 26.04 & 29443 & 29.59 \\
\hline Passed & 34194 & 73.93 & 70106 & 70.42 \\
\hline Total & 46234 & 100.00 & 99549 & 100.00 \\
\hline
\end{tabular}

b) Inferential Statistics: Table 4 presents the results of the test for association between binary outcome (passed/not passed) and the provinces. The number of learners who passed matric $(\mathrm{n}=104300$ [71.54\%]) were marginally higher than those who did not pass $(n=41483$ [28.46\%]). A Pearson's chi-square test for association, shown in Table 4, was performed to examine the correlation between province and study endpoint. The proportion of learners who passed matric to the proportion of those who did not pass matric differed significantly in the two provinces $(\mathrm{p}<0.001)$. Therefore, performance in the two provinces differed significantly, with the Western Cape Province being in favour.

Table 4: Test for association between province and study end-point

\begin{tabular}{lccccc}
\hline \multirow{2}{*}{ Province } & \multicolumn{2}{c}{ Not passed } & \multicolumn{2}{c}{ Passed } & \multirow{2}{*}{ Total } \\
& Count & Percent & Count & Percent & \\
\hline Gauteng & 29443 & 29.58 & 70106 & 70.42 & 99549 \\
Western Cape & 12040 & 26.04 & 34194 & 73.96 & 46234 \\
Total & 41483 & 28.46 & 104300 & 71.54 & 145783 \\
\hline & $\chi_{(1)}^{2}=193.7835$ & $p<0.0001$ & \\
\hline
\end{tabular}

Table 5 presents the results of the unadjusted hierarchical logistic regression model. Learners in the Western Cape Province were significantly 1.1928 more likely to pass matric than learners in Gauteng province ( $\mathrm{p}<$ $0.001, \mathrm{OR}=1.193,95 \% \mathrm{CI}: 1.164-1.223$ ). The odds of passing matric increased significantly by a factor of 
about 1.19 for Western Cape Province over that of Gauteng Province. Therefore, the hypothesis that the chances of passing matric in the two provinces were the same was not accepted at $95 \%$ confidence limit.

Table 5: Crude estimates

\begin{tabular}{|c|c|c|c|c|c|c|c|}
\hline Outcome & & OR & Std. Err. & $\mathbf{z}$ & $P>|z|$ & \multicolumn{2}{|c|}{ [95\% Conf. Interval] } \\
\hline \multicolumn{8}{|l|}{ Province } \\
\hline & Gautenga & & & & & & \\
\hline & Western Cape & 1.1928 & 0.0150 & 13.98 & $<0.001$ & 1.1636 & 1.2226 \\
\hline Constant & & 2.3817 & 0.0165 & 125.52 & $<0.001$ & 2.3497 & 1.4142 \\
\hline
\end{tabular}

Table 6 presents the estimates after adjusting for learner-gender and school quintile. School quintile is a significant predictor of the outcome $(p<0.001)$ while gender hardly predicts the outcome. Thus, school quintile significantly predicted the outcome in favour of the Western Cape Province. Learners in the Western Cape Province were significantly 1.5123 more likely to pass matric than learners in Gauteng province (p < $0.0001, \mathrm{OR}=1.512,95 \% \mathrm{CI}: 1.471-1.555)$. The odds of passing matric increased significantly by a factor of about 1.51 for Western Cape Province, over that of Gauteng province.

Table 6: Model estimates after adjusting for gender and school quintile

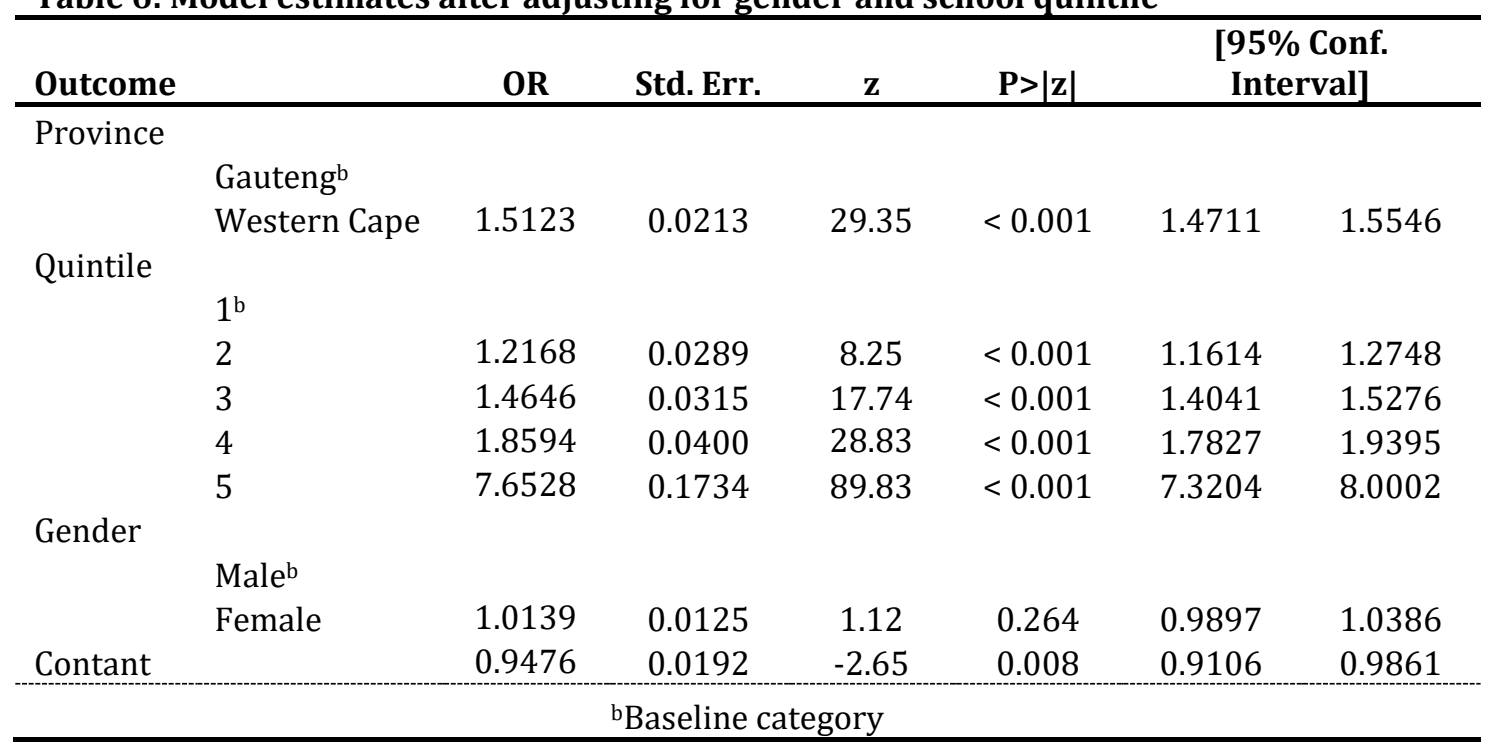

Table 7 indicates that school quintile is a significant predictor of the binary outcome $(p<0.001)$. The result in the adjusted model indicates that learners in the Western Cape province were 1.5122 more likely to pass matric when compared to learners in Gauteng province ( $p<0.001$, OR $=1.512,95 \% C I$ : $1.471-1.555$ ). Therefore, there is sufficient evidence that after taking into account subject-type, learner-gender and school quintile, learners in the Western Cape province were significantly more likely to pass matric than learners in Gauteng province. 
Table 7: Model estimates after adjusting for gender, quintile and subject-type

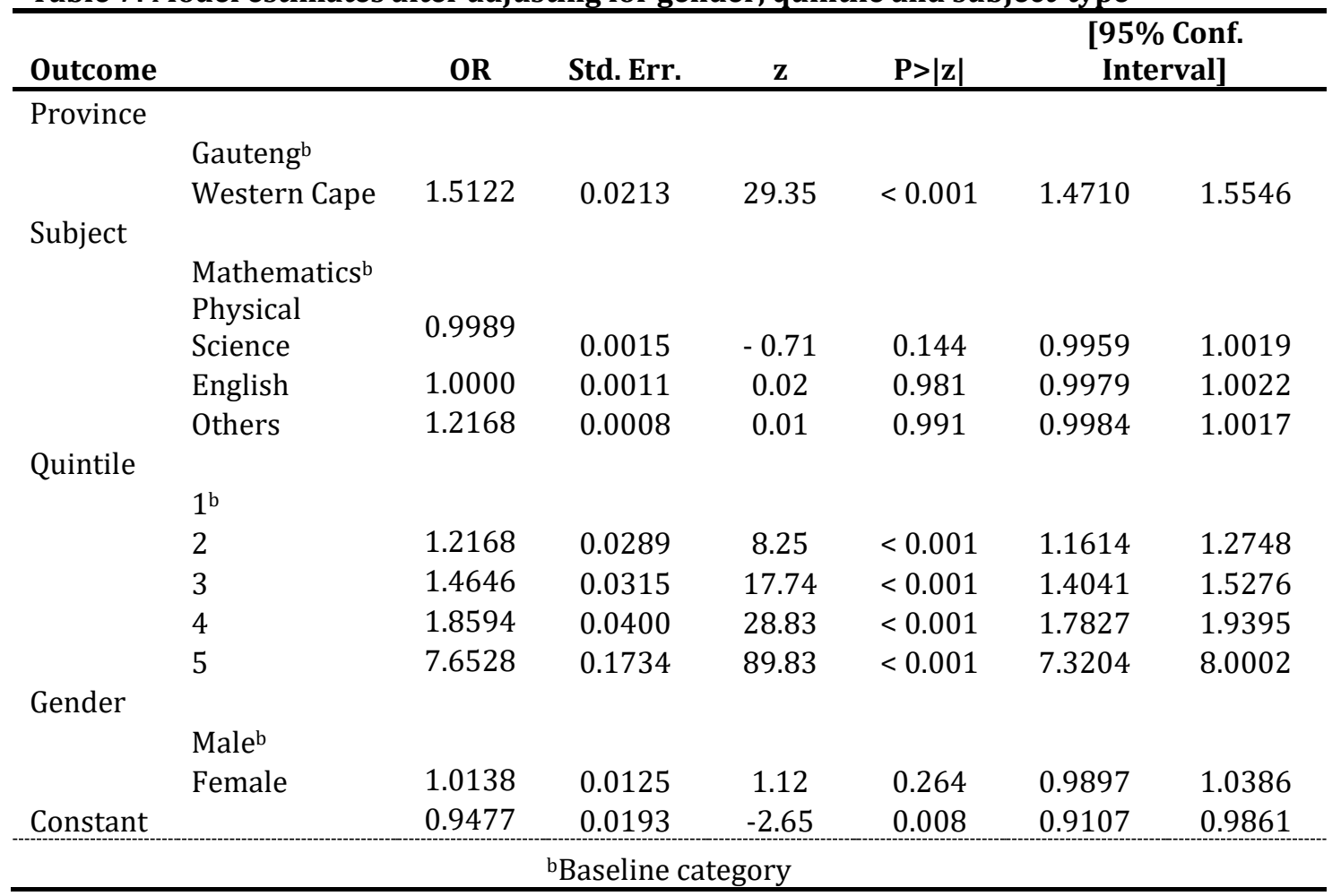

Therefore, if the school quintile was constant (i.e., if all schools were resourced equitably or equally), learnergender was constant (all learners were of the same gender) and subjects were fixed (all subjects were the same) then the chance of passing matric was 1.512 more likely for the Western Cape Province than for Gauteng Province. Clearly, the odds of passing matric increased from 1.193 (crude estimate) to 1.512 (adjusted model). Although subject-type was found not to be a significant predictor of the binary outcome, its effect increased the chances of passing matric in the Western Cape Province.

\section{Conclusion and Recommendations}

In view of the findings of this study, based on the literature review and the empirical investigation, it can be concluded that:

The absence or inadequate educators, especially in the STEM subjects in basic schools, presents a major obstacle to the achievement of quality education, capacity building and the development of human resources. Educators, who educate the youth who are the leaders of the next generation of people, are an extremely important component of any society for a multitude of reasons (Owusu-Acheampong \& Williams, 2015). Therefore, it is recommended that only properly or truly trained qualified educators should teach mathematics and physical science, especially in secondary schools. Training of under-qualified educators should be provided to enable them to adapt their teaching thereby improving performance of learners in the STEM subjects.

Based on the results from other studies, e.g. Owalabi (2012) and (Charles-Ogan \& Okey, 2017), it is recommended that physical science learners should be properly groomed in mathematics, problem-solving schedules should accompany conceptual treatment of numerical problems in the physics classroom. Furthermore, it is recommended that learners, especially in the year of examination, should be taught by properly qualified and experienced educators. Prior research points to the importance of learners' selfrealisation to achieve educational outcomes, which could be influenced by interventions that directly counteract learners' stereotypical beliefs (Dar-Nimrod \& Heine, 2006) or affirm their personal values more broadly, resulting in increased engagement, grit, or confidence (Miyake, et al., 2010). Gender in secondary 
schools is a prominent issue that has been a focus of many studies, notably Guiso, Ferdinando, Paolo \& Luigi (2008) and Letsoalo, Maoto, Masha \& Lesaoana (2016). Researchers have not reached consensus. Some studies show female learners outperforming male learners (Stevens, Wang, Olivarez, \& Hamman, 2007) while others indicate male learners outperforming female learners (Hedges \& Nowell, 1995). Therefore, male learners are not innately better at mathematics and/or physical science than female learners and vice versa. It can be concluded that any difference in test or examination scores is due to nurture (which may be stereotyping) rather than nature. Use of innovative teaching strategies would improve interactivity, understanding, and application of concepts (numerical and non-numerical) in the learning of mathematics and physical science classrooms. Further, it is recommended that the conditions for co-operative learning, namely Learner-centered approaches, be encouraged in South African schools, particularly in the two provinces because a co-operative learning approach could foster a positive attitude towards mathematics and physical science among learners. Therefore, adequately empowered educators, especially those that teach science subjects need to be made aware of the benefits and importance of co-operative learning. This approach changes the practice of educator-centred teaching approaches to learner-centred teaching strategies. This could be because learners who work in group feel that they can depend on one another for help thereby increasing their confidence in solving physical science or mathematics problems. This approach has the potential to change their attitude towards these subjects.

Results of this study indicate that the Western Cape Province provided better conditions for learners to pass matric. Strategies to empower mathematics and science educators should be intensified, especially in Gauteng Province. The current policy advocates for general approach or embraces a single-minded approach, which can be regarded as "one-size-fits-all" approach that does not recognise within-province dynamics. There is a need for differentiation in support approach since the dynamics in each province is different. Also, for Gauteng Province to perform on par with the Western Cape Province, a special mixed-approach designed study that will concentrate only on Gauteng province should be commissioned to gain more insight into those issues that affect teaching and learning of mathematics and physical science. To improve performance in mathematics and physical science, policy makers need to realise the effect of affective factors, and be aware of those factors that influence learners' performance. Finally, the researcher recommends that similar studies be conducted in all other provinces of South Africa involving all matriculation cohorts.

Conflict of Interest: The author declares that he has no financial or personal relationship(s) that could have influenced him inappropriately in writing this article.

Acknowledgements: The author would like to expresses his sincere gratitude to Given Luvhimbi (Information Librarians: Tshwane University of Technology), Alice Machele (Client Manager Services: Tshwane University of Technology) for technical assistance, Peggy J Ahrens for language editing and the Umalusi Council for allowing him to use the Grade 12 dataset.

\section{Reference}

Abe, T. 0. (2014). The effect of teachers' qualifications on students' performance in mathematics. Sky Journal of Educational Research, 2(1), 10 - 14.

Adewuyi, T. D., Taiwo, O. K. \& Olley, B. 0. (2012). Influence of examination anxiety and self-efficacy on academic performance among secondary school students. IFE Psychol., 20(2), 60 - 68.

Adeyemi, T. 0. (2007). Mathematics as a language for involving secondary school children in science and technology in Ondo State, Nigeria. Mathematics connection, 6, 11 - 21.

Asante, 0. A. (2010). Sex differences in mathematics performance among senior high students in Ghana. Gender and Behaviour, 8(2), 3279 - 3289.

Bansilal, S., James, A. \& Naidoo, M. (2010). Whose voice matters? Learners. South African Journal of Education, $30,153-165$.

Barrows, J., Dunn, S. \& Lloyd, C. A. (2013). Anxiety, self-effficacy, and college exam grades. Universal Journal of Educational Research, 1(3), 204 - 208.

Battle, J. \& Lewis, M. (2002). The increasing significance of class: The relative effects of race and socioeconomic status on academic achievement. Journal of Poverty, 6(2), 21 - 35. 
Breslich, E. (1966). Importance of mathematics in general education. The Mathematics Teacher, 59(5), 464 469.

Campbell, G. \& Prew, M. (2014). Behind the matric results: The story of maths and science. Mail and Guardian.

Carnevale, A. P. (2005). Education and the economy: If we're so dumb, why are we so rich? Education Week, 24(21), 40 - 41.

Charles-Ogan, G. I. \& Okey, I. F. (2017). Effects of mathematics knowledge on physics students performance in electromagnetism. International Journal of Theoretical and Mathematical Physics, 7(4), 61 - 67.

Chowa, G. A., Masa, R. D., Ramos, Y. \& Ansong, D. (2015). How do student and school characteristics influence youth academic achievement in Ghana? A hierarachical linear modeling of Ghana YouthSafe baseline data. International Journal of Education Development, 45, 129 - 140.

Clark, N. L. \& Worger, W. H. (2004). South Africa: The rise and fall of apartheid. Cape Town: Pearson Longman.

Cohen, L., Manion, L. \& Morisson, K. (2000). Research methods in education. London: Routledge Falmer.

Dalton, E. M., Mckenzie, J. A. \& Kahonde, C. (2012). The implementation of inclusive education in South Africa: Reflections arising from a workshop for teachers and therapists to introduce universal design for learning. Journal of Disability, 1(1), 7 - 23.

Dar-Nimrod, I. \& Heine, S. J. (2006). Exposure to scientific theories affects women's math performance. Science, 314, 435.

Demirbas, O. \& Demirkan, H. (2007). Learning styles of design students and the relationship of academic performance and gender in design education. Learning and Instruction, 17, 345 - 359.

Department of Education. (1997). Curriculum 2005: Lifelong learning for the 21st century. Pretoria: Government Printer.

Department of Education. (2003). National Curriculum Statement Grade 10 - 12 (General). Pretoria: Government Printers.

Eccles, J. S. \& Midgley, C. (1989). Stage/environment fit: Developmentally appropriate classrooms for early adolescents. In R. E. Ames, \& C. Ames, Research on motivation in research (pp. 139 - 181). New York: Academic Press.

Englund, M., Luckner, E., Amy, W. J. \& Egeland, B. (2004). Children's achievement in early elementary school: Longitudinal effects of parental involvement, expectations, and quality of assistance. Journal of Educational Psychology, 96(4), 723 - 730.

Faize, F. A. \& Dahar, M. A. (2011). Effect of mother's level of education on secondary Grade Science students in Pakistan. Research Journal of International Studies, 19, 13 - 19.

Fan, X. \& Chen, M. (2001). Parental involvement and students' academic achievemen: A meta-analysis. Educational Psychology Review, 13(1), 1 - 22.

Fentiman, A., Hall, A. \& Bundy, D. (1999). School enrolment patterns in rural Ghana: A comparative study of the impact of location, gender, age, and health on children's access to basic schooling. Comp. Educ., $35(3), 331$ - 349.

Filmer, D. (2005). Gender and wealth disparities in schooling: Evidence from 44 countries. Int. J. Educ., 43(6), $351-369$.

Griffin, G. A. (1983). Introduction: The work of staff development. In G. A. Griff, Staff development. Eightysecond yearbook of the National Society for the Study of Education. Chicaco: University of Chicago Press.

Guiso, L., Ferdinando, M., Paolo, S. \& Luigi, Z. (2008). Culture, Gender and Math. Science, 320(5880), 1164 1165.

Guskey, T. R. (1986). Staff development and the process of teacher change. Educational Review, 15(5), 5 - 12.

Hakkinen, I., Kirjavainen, T. \& Uusitalo, R. (2003). School resources and student achievement revisited: New evidence from panel data. Economics of Education Review, 22, 329 - 335.

Haladyna, T., Shaughnessy, J. \& Shaughnessy, J. M. (1983). A causal analysis of attitude towards mathematics. Journal for Research in Mathematics Education, 14, 19 - 20.

Halpern, D. F., Benbow, C. P., Geary, D. C., Gur, R. C., Hyde, J. S. \& Gernsbacher, M. A. (2007). The science of sex differences in science and mathematics. Psychological Science in the Public Interest, 8(1), 1 - 51.

Hannula, M. S. (2002). Attitude towards mathematics: Emotions, expectations and values. Educational Studies in Mathematics, 49(1), 25 - 46.

Hart, L. (1989). Describing the affective domain: Saying what we mean. In D. B. McLeod, \& V. M. Adams, Affect and mathematical problem solving (pp. 37 - 45). New York: Springer Verlag. 
Hazari, Z., Potvin, G., Lock, R. M., Lung, F., Sonnert, G. \& Sadler, P. M. (2013). Factors that affect the physical science career interest of female students: Testing five common hypotheses. Physics Education Research, 020115-1 - 020115-8. doi:10.1103/PhysRevSTPER.9.020115

Hedges, L. V. \& Nowell, A. (1995). Sex differences in mental test scores, variability, and numbers of highscoring individuals. Science, 269(5220), 41 - 45.

Hosmer, D. W., Lemeshow, S. \& Sturdivant, R. X. (2013). Applied Logistic Regression (3rd ed.). Hoboken, USA: John Wiley \& Sons, Inc.

Jehangir, F., Tahir, S. A. \& Tahir, S. (2000). Parental education: A contributing factor to personality. The Journal of Psychology, 2, 5 - 13.

Kanjere, M. \& Mafumo, T. (2017). The significance of training school principals and educators in managing inclusive education. Gender and Behaviour, 15(2), 8646 - 8648.

Kyei, K. A. \& Maboko, T. (2016). Performance of high school students in Vhembe district. Journal of Economics and Behavioural Studies, 8(1), 50 - 57.

Kyei, K. A. \& Nemaorani, T. M. (2014). Establishing factors that affect performance of Grade Ten students in high school: A case study of Vhembe District in South Africa. Journal of Emerging Trends in Educational Research and Policy Studies, 5(7), 83 - 87.

Kyei, K. \& Ramagoma, M. (2013). Alcohol consumption in South African Universities: Prevalence and factors at the University of Venda, Limpopo Province. J Soc Sci, 36(1), 77 - 86.

Lee, V. E., Zuze, T. L. \& Ross, K. N. (2005). School effectiveness in 14 sub-Saharan African countries: Links with 6th Graders' reading achievement. Stud. Educ. Eval., 31(2 - 3), 207 - 246.

Letsoalo, M. E. (2017a). Disaggregated analysis of performances of Grade 12 learners in Gauteng Province, Republic of South Africa. Journal of Education and Vocational Research, 8(2), 34 - 44.

Letsoalo, M. E. (2017b). Learners' perceptions on factors that affect their overall performances in mathematics. Gender and Behaviour, 15(3), 9502 - 9523.

Letsoalo, M. E., Maoto, R. S., Masha, J. K. \& Lesaoana, M. A. (2016). Gender as a unit of analysis: Performance of male and female learners in Gauteng and Western Cape Provinces of South Africa. Gender and Behaviour, 14(2), $7504-7512$.

Letsoalo, M. E., Maoto, R. S., Masha, J. K. \& Lesaoana, M. A. (2017). The effect of gender on learner achievement in Gauteng and the Western Cape Provinces of South Africa. Gender and Behaviour, 15(2), 9177 9184.

Lilis. \& Togi. (2017). The differences of realization ability between students' learning model problem-based discovery learning model in Smk Private Laksamana Martadinata Medan. World Journal of Educational Research, 4(4), 496 - 515.

Maslow, A. H. (1943). A theory of human motivation. Psychological Review, 50, 370 - 396.

McLeod, D. B. (1994). Research on affect and mathematics learning in the JRME: 1970 to present. Journal for Research in Mathematics Education, 24, 637 - 647.

Miyake, A., Kost-Smith, L. E., Finkelstein, N. D., Pollock, S. J., Cohen, G. L. \& Ito, T. A. (2010). Reducing the gender achievement gap in college science: A classroom study of values affirmation. Science, 330, 1234.

Murray, D. M. (1998). Design and analysis of group-randomized trials. New York: Oxford University Press.

Ogunleye, A., Awofala, A. O. \& Adekoya, E. A. (2014). Effect of students' background knowledge of mathematics on senior secondary school students achievements' in physics. Chemistry: Bulgarian Journal of Science Education, 23(6), 863 - 880.

Ojera, D. A. (2016). Impact of teacher qualification on pupils' academic achievements in Kenya certificate of primary education in public primary schools of Migori County, Kenya. World Journal of Educational Research, 3(7), 1 - 20.

Owalabi, T. (2012). Effect of teacher's aualification on the performance of senior secondary school physics students: Implication on technology in Nigeria. English Language Teaching, 5(6), 72 - 77.

Owusu-Acheampong, E. \& Williams, A. A. (2015). Dearth of teachers in rural basic schools: Implications on human resource development in the Amenfi West District, Ghana. British Journal of Education, 3(1), $32-43$

Peters, H. \& Mullis, N. (1997). The role of family income and sourcs of income in adolescent achievement. In G. Duncan, \& J. Brook-Gunn, Consequences of growing up poor (pp. 340 - 381). New York: Russel Sage Foundation Press. 
Preckel, F., Goetz, T., Pekrun, R. \& Kleine, M. (2008). Gender differences in gifted and average-ability students: Comparing girls' and boys' achievement, self-concept, interest, and motivation in mathematics. Gifted Child Quarterly, 52(2), 146 - 159.

Rabe-Hesketh, S. \& Skrondal, A. (2005). Multilevel and longitudinal modeling using Stata. Texas: Stata Press.

Rogers, W. T. (1997). Socio-economic status strong predictor of performance. Alberta Teachers' Association Publication, 32(3).

Scarpello, G. (2007). Helping students get past math anxiety. Techniques: Connecting Education and Careers (J1), 82(6), 34 - 35.

Singh, P., Mbokodi, S. M. \& Msila, V. T. (2004). Black parental involvement in education. South African Journal of Education, 24(4), 301 - 307.

Skrondal, A.,] \& Rabe-Hesketh, S. (2004). Generalized latent variable modeling: Multilevel, longitudinal, and structural equation models. New York: Chapman and Hall/CRC.

StataCorp. (2017). Stata Statistical Software: Release 15. College Station, TX: StataCorp LLC.

Steele, J. R. \& Ambady, N. (2006). "Math is hard!" The effect of gender priming on women's attitude. Journal of Experimental Social Psychology, 42, 428 - 436.

Stevens, T., Wang, K., Olivarez, A. \& Hamman, D. (2007). Use of self-perspectives and their sources to predict the mathematics enrollment intentions of girls and boys. Sex Roles, 56, 351 - 363.

Stoet, G. \& Geary, D. C. (2013). Sex differences in mathematics and reading achievement are inversely related: within- and across-nation assessment of 10 Years of PISA data. PLOS ONE, 8(3), e57988.

Sudhir, M. A. \& Lalhirimi, S. (1989). Parent Child interaction and achievement among secondary school students in Aizwi. Psychological Abstract, 78(1).

Sunday, O. S. \& Zaku, J. A. (2013). Gender snalysis of students' entry qualification in English language in college of education in Kwasa State. International Journal of Secondary Education, 1(5), 23 - 25.

Szumilas, M. (2010). Explaining Odds Ratios. Journal of the Canadian Academy of Child and Adolescent Psychiatry, 19(3), 227 - 229.

Tansel, A. (2002). Determinants of school attainment of boys and girls in Turkey: Individual, household and community factors. Econ. Educ. Rev., 21(5), 455 - 470.

Thoonen, E. E., Sleegers, P. J., Peetsma, T. T. \& Oort, F. J. (2011). Can teachers motivate students to learn? Educational Studies, 37(3), 345 - 360.

Visser, M., Juan, A. \& Feza, N. (2015, February). Home and school resources as predictors of mathematics performance in South Africa. South African Journal of Education, 35(1), 1 - 10.

Wu, H. \& Zhang, J. T. (2006). Nonparametric regression methods for longitudinal data analysis: Mixed-effect modeling approach. New York: John Wiley \& Sons, Inc. 